\title{
Retraction Note to: Input Displacement Neuro-fuzzy Control and Object Recognition by Compliant Multi-fingered Passively Adaptive Robotic Gripper
}

\author{
Dalibor Petković ${ }^{1}$ - Shahaboddin Shamshirband ${ }^{2}$ - Nor Badrul Anuar ${ }^{2} \cdot$ Aznul Qalid Md Sabri $^{2}$. \\ Zulkanain Bin Abdul Rahman ${ }^{3}$. Nenad D. Pavlović ${ }^{1}$
}

Published online: 19 August 2019

(C) Springer Nature B.V. 2019

Retraction Note to: J Intell Robot Syst (2016) 82:177-187

https://doi.org/10.1007/s10846-015-0182-6

The Editor-in-Chief has retracted this article [1] because validity of the content of this article cannot be verified. This article showed evidence of substantial text overlap (most notably with the article cited [2]) and authorship manipulation. None of the co-authors agree to this retraction.

\section{References}

1. Petković, D., Shamshirband, S., Anuar, N.B. et al. J. Intell. Robot. Syst. (2016) 82: 177. https://doi.org/10.1007/s10846-015-0182-6

2. Petković, D., Issa, M., Pavlovic, N.D. et al. Expert Syst. Appl. (2012) 39: 13295-13304. https://doi.org/10.1016/j.eswa.2012.05.072

Publisher's Note Springer Nature remains neutral with regard to jurisdictional claims in published maps and institutional affiliations.

The online version of the original article can be found at https://doi.org/ 10.1007/s10846-015-0182-6

Dalibor Petković

dalibortc@gmail.com

Shahaboddin Shamshirband

shamshirband@um.edu.my

1 Faculty of Mechanical Engineering, Deparment for Mechatronics and Control, University of Niš, Aleksandra Medvedeva 14, Niš 18000 , Serbia

2 Department of Computer System and Technology, Faculty of Computer Science and Information Technology, University of Malaya, 50603 Kuala Lumpur, Malaysia

3 Department of History, Faculty of Arts and Social Sciences Building, University of Malaya, 50603 Kuala Lumpur, Malaysia 